\title{
ECONOMETRIC FORECAST OF AGRICULTURAL SECTOR INVESTING IN LVOV REGION
}

\author{
Rostyslav Lytvyn, Research assistant \\ Lvov national university of veterinary medicine and biotechnologies \\ named after S.Z. Gzhytskyj, Lvov, Ukraine \\ E-mail: lytvynr@ukr.net
}

\begin{abstract}
Purpose of economic processes forecasting in agriculture is more relevant and urgent in recent years with application of applied econometric methods. In represented research paper, these methods are used to forecast investment and the main agricultural industry indicators of Lvov region of Ukraine. The linear trend model, the parabolic trend model and the exponential trend model were elaborated from the period from 2000 to 2009 in this scientific study using applied statistical tool STATGRAFICS and EXCEL spreadsheets. And with assistance of these models forecast for investment on the basis of data of essential indicators of agrarian sector of the region for 2010 and 2011 was made. All models with probability $p=0,95$ are adequate experimental data for 2000-2009 years, that allow to make the forecast of investments and main agricultural indicators of the researched region by these models for 2010 and 2011 years. Nevertheless, it should be pointed out that, because of small amount of input data analysis of regression equations coefficients have more qualitative than quantitative influence upon resulting variable $\mathrm{y}_{6}$.
\end{abstract}

\section{KEY WORDS}

Investment; Agrarian sector; Forecasting; Linear trend model; Parabolic trend model; Exponential trend model.

Accordingly to statistical data of agricultural sector of Lvov region and Ukraine provided by State Statistical Service of Ukraine for 2000-2009 years, presented in tables (1) in this applied research calculate main dynamics and trend models and calculate predicted values and their estimates for forthcoming two years with application of the applied statistical tool STATGRAFICS and EXCEL spreadsheets.

To vital issues of investing processes in agriculture of Ukraine's economy have dedicated one's researches many prominent scientists, among them: A. Carita, I. Luyt, N. Santos et al. [1], K. Crane, F.S. Larrabee [2], K. Vitale [3] and others. In this research one's attention is paid to study investment of agriculture of Ukraine and another developing economies with assistance of econometric methods, that are displayed in scientific works of: V. Yeleyko, O. Yeleyko, I. Kopych, R.. Bodnar, M. Demchyshyn, O. Synytskyy, A. Chemerys [4-7], M.I. Gómez, E.R. Gonzáles, L.F. Melo [8], F. Ruff [9], N. Carnot, V. Koen, B. Tissot [10], R.S. Mariano, Y.K. Tse [11] and R. Gupta, A. Kabundi [12].

Input data of the models:

Table 1 - Dynamics of agricultural sector main indicators of Lvov region

\begin{tabular}{|c|c|c|c|c|c|}
\hline Year & $\begin{array}{c}\text { У6 } \\
\text { bln. UAH }\end{array}$ & $\begin{array}{c}\text { У7 } \\
\text { mln. UAH }\end{array}$ & $\begin{array}{c}\text { У8 } \\
\text { mln. USD }\end{array}$ & $\begin{array}{c}\text { У9 } \\
\text { mln. pers. }\end{array}$ & $\begin{array}{c}\text { У10 } \\
\text { m.n. UAH }\end{array}$ \\
\hline 2000 & 5,850 & 48,3 & 2,412 & 0,267 & 10,5 \\
\hline 2001 & 7,305 & $-4,2$ & 2,412 & 0,283 & 18,8 \\
\hline 2002 & 8,578 & $-7,0$ & 2,935 & 0,285 & 14,2 \\
\hline 2003 & 10,547 & 45,0 & 0,041 & 0,228 & 30,7 \\
\hline 2004 & 13,992 & 63,2 & 0,064 & 0,216 & 40,3 \\
\hline 2005 & 17,192 & 70,8 & 0,438 & 0,213 & 75,1 \\
\hline 2006 & 21,486 & 166,3 & 0,612 & 0,189 & 84,0 \\
\hline 2007 & 27,987 & 231,9 & 1,653 & 0,188 & 211,0 \\
\hline 2008 & 35,534 & 77,7 & 31,783 & 0,177 & 549,8 \\
\hline 2009 & 39,893 & 17,9 & 91,482 & 0,175 & 321,9 \\
\hline
\end{tabular}

Source: State Statistic Service of Lvov region and Ukraine [13,14]. 
Here comes:

$\mathrm{y}_{6}$ - gross regional product (Lvov region) in actual prices, in bln. UAH;

mln. $\mathrm{UAH}$;

$\mathrm{y}_{7}$ - financial result of general activity (agriculture) of Lvov region before taxation, in

$\mathrm{y}_{8}$ - foreign direct investment in agriculture (Lvov region), in mln. USD;

$\mathrm{y}_{9}-$ quantity of the employed persons in agriculture of Lvov region, in mln. pers.;

$\mathrm{y}_{10}-$ investment in capital assets (agriculture) of Lvov region, in mln. UAH.

Econometric forecast models. Thus linear $\left(\tilde{y}^{\text {lin }}\right)$, parabolic $\left(\tilde{y}^{\text {par }}\right)$ and exponential $\left(\tilde{y}^{\text {exp }}\right)$ trend models will look like:

$$
\begin{aligned}
& \tilde{y}_{6}^{\operatorname{lin}}=-2,39867+3,86092 \cdot t \\
& \tilde{y}_{6}^{\text {par }}=6,16267-0,41974 \cdot t+0,38915 \cdot t^{2} \\
& \tilde{y}_{6}^{\exp }=\exp \{1,51972+0,22185 \cdot t\} \\
& \tilde{y}_{7}^{\operatorname{lin}}=15,3333+10,5267 \cdot t \\
& \tilde{y}_{7}^{\text {par }}=-55,3167+45,8517 \cdot t-3,21136 \cdot t^{2} \\
& \tilde{y}_{7}^{\exp }=\exp \{2,62598+0,20017 \cdot t\} \\
& \tilde{y}_{8}^{\operatorname{lin}}=-20,0469+6,07821 \cdot t \\
& \tilde{y}_{8}^{\text {par }}=31,8863-19,8884 \cdot t+2,3606 \cdot t^{2} \\
& \tilde{y}_{8}^{\exp }=\exp \{-1,52552+0,35111 \cdot t\} \\
& \tilde{y}_{9}^{\operatorname{lin}}=0,2946-0,01318 \cdot t \\
& \tilde{y}_{9}^{\text {par }}=0,3056-0,01868 \cdot t+0,00050 \cdot t^{2} \\
& \tilde{y}_{9}^{\exp }=\exp \{-1,19592-0,05906 \cdot t\} \\
& \tilde{y}_{10}^{\operatorname{lin}}=-120,98+46,6564 \cdot t \\
& \tilde{y}_{10}^{\text {par }}=54,0783-40,8728 \cdot t+7,9572 \cdot t^{2} \\
& \tilde{y}_{10}^{\exp }=\exp \{1,73874+0,43376 \cdot t\}
\end{aligned}
$$

\begin{tabular}{|c|c|c|c|c|c|}
\hline \multirow{2}{*}{ Indicator } & \multicolumn{2}{|c|}{ Indicator forecast } & \multirow{2}{*}{ ME } & \multirow{2}{*}{ MSE } & \multirow{2}{*}{ MAE } \\
\hline & 2010 & 2011 & & & \\
\hline 1 & 2 & 3 & 4 & 5 & 6 \\
\hline \multicolumn{6}{|c|}{ bln. UAH } \\
\hline$\tilde{y}_{6}^{\operatorname{lin}}$ & 40,071 & 43,932 & 0 & 8,4881 & 2,6473 \\
\hline$\tilde{\mathrm{y}}_{6}^{\text {for }}$ & 48,633 & 57,163 & 0 & 0,4921 & 0,5402 \\
\hline$\tilde{\mathrm{y}}_{6}^{\text {exp }}$ & 52,459 & 65,489 & 0,0132 & 0,9590 & 0,6575 \\
\hline \multicolumn{6}{|c|}{ mIn. UAH } \\
\hline$\tilde{y}_{7}^{\operatorname{lin}}$ & 131,127 & 141,653 & 0 & 3845,42 & 46,4147 \\
\hline$\tilde{\mathrm{y}}_{7}^{\text {for }}$ & 60,477 & 32,467 & 0 & 3300,90 & 48,9838 \\
\hline$\tilde{y}_{7}^{\exp }$ & 124,939 & 152,626 & 24,4689 & 4905,24 & 143,899 \\
\hline \multicolumn{6}{|c|}{ mln. USD } \\
\hline$\tilde{y}_{8}^{\operatorname{lin}}$ & 46,813 & 52,891 & 0 & 456,364 & 16,4355 \\
\hline$\tilde{\mathrm{y}}_{8}^{\text {for }}$ & 98,747 & 133,152 & 0 & 162,139 & 10,8384 \\
\hline$\tilde{y}_{8}^{\exp }$ & 10,347 & 14,699 & 10,9969 & 782,519 & 12,4516 \\
\hline \multicolumn{6}{|c|}{ mln. Pers. } \\
\hline$\tilde{y}_{9}^{\operatorname{lin}}$ & 0,150 & 0,136 & 0 & 0,00020 & 0,0116 \\
\hline
\end{tabular}

where $\tilde{y}_{i}(i=1,2, \ldots, 10)$ - regulatory or averaged values of the researched indicators; $t-$ time.

Relevant predicted values and their estimates based on trends (1) - (15) were calculated, that are displayed in table (2). Here: ME - mean value of the error; MSE - mean square value of the error; MAE - mean absolute value of the error. It is necessary to notice that the closer the values of ME, MSE and MAE to zero, the better will be calculated forecasts value of the appropriate indicators.

Table 2 - Forecasting values and estimation indicators of Lvov region's agricultural sector 


\begin{tabular}{|c|c|c|c|c|c|}
\hline 1 & 2 & 3 & 4 & 5 & 6 \\
\hline$\tilde{y}_{9}^{\text {for }}$ & 0,161 & 0,153 & 0 & 0,00019 & 0,0103 \\
\hline$\tilde{y}_{9}^{\exp }$ & 0,158 & 0,149 & 0,00039 & 0,00019 & 0,0104 \\
\hline \multicolumn{6}{|c|}{ mIn. UAH } \\
\hline$\tilde{y}_{10}^{\text {lin }}$ & 392,240 & 438,896 & 0 & 10280,6 & 76,4327 \\
\hline$\tilde{y}_{10}^{\text {for }}$ & 567,298 & 709,441 & 0 & 6937,49 & 51,5211 \\
\hline$\tilde{y}_{10}^{\text {exp }}$ & 671,917 & 1036,80 & 13,5174 & 8665,66 & 47,0208 \\
\hline
\end{tabular}

Forecast with the least gross regional product error (Lvov region) receive on the basis of parabolic trend model (2):

$$
\tilde{y}_{6,2010}^{\text {forecast }}=48,633 \text { bln. UAH and } \tilde{y}_{6,2011}^{\text {forecast }}=57,163 \text { bln. UAH }
$$

Forecast with the least financial result of general activity (agriculture) before taxation error (Lvov region) receive with the assistance of parabolic trend model (5):

$$
\tilde{y}_{7,2010}^{\text {forecast }}=60,477 \mathrm{mln} . \cup A H \text { and } \tilde{y}_{7,2011}^{\text {forecast }}=32,467 \mathrm{mln} . \cup A H
$$

Forecast with the least foreign direct investment in agriculture error (Lvov region) receive on the basis of parabolic trend model (8):

$$
\tilde{y}_{8,2010}^{\text {forecast }}=98,744 \mathrm{mln} . \text { USD and } \tilde{y}_{8,2011}^{\text {forecast }}=133,152 \mathrm{mln} \text {. USD }
$$

Forecast with the small error of persons quantity employed in agriculture (Lvov region) receive on the basis of parabolic trend model (11):

$$
\tilde{y}_{9,2010}^{\text {forecast }}=0,161 \mathrm{mln} \text {. Pers. and } \tilde{y}_{9,2011}^{\text {forecast }}=0,153 \mathrm{mln} \text {. Pers.; }
$$

as well as on the basis of exponential trend model (12):

$$
\tilde{y}_{9,2010}^{\text {forecast }}=0,158 \mathrm{mln} \text {. Pers. and } \tilde{y}_{9,2011}^{\text {forecast }}=0,149 \mathrm{mln} \text {. }
$$

Pers. and linear (10) trend model:

$$
\tilde{y}_{9,2010}^{\text {forecast }}=0,150 \mathrm{mln} \text {. Pers. and } \tilde{y}_{9,2011}^{\text {forecast }}=0,136 \mathrm{mln} \text {. Pers. }
$$

Forecast with the least investments in capital assets error (agriculture) (Lvov region) receive with the assistance of parabolic trend model (14):

$$
\tilde{y}_{10,2010}^{\text {forecast }}=567,298 \mathrm{mln} \text {. UAH and } \tilde{y}_{10,2011}^{\text {forecast }}=709,441 \mathrm{mln} \text {. UAH }
$$

Simple and multiple regression equations dependence of gross regional product (Lvov region) $\left(\mathrm{y}_{6}\right)$ and financial result of general activity (agriculture) of Lvov region $\left(\mathrm{y}_{7}\right)$ on influence of the studied indicators on the basis data tables (2) were elaborated.

$$
\begin{aligned}
& \tilde{y}_{6}=14,64621+0,31309 \cdot y_{8}, \\
& R^{2}=0,56754 ; \quad F=10,4990 ; \\
& \tilde{y}_{6}=10,65241+0,06034 \cdot y_{10}, \\
& R^{2}=0,78208 ; \quad F=28,7107 ;
\end{aligned}
$$




$$
\begin{aligned}
& \tilde{y}_{6}=10,74635+0,13442 \cdot y_{8}+0,04638 \cdot y_{10}, \\
& R^{2}=0,84485 ; \quad F=19,0593 ; \\
& \tilde{y}_{6}=44,7041+0,12285 \cdot y_{8}-138,50257 \cdot y_{9}+0,02396 \cdot y_{10}, \\
& R^{2}=0,96301 ; \quad F=52,0693 ; \\
& \tilde{y}_{6}=26,43394+0,04147 \cdot y_{7}+0,19455 \cdot y_{8}-74,39491 \cdot y_{9}+0,02422 \cdot y_{10}, \\
& R^{2}=0,98242 ; \quad F=69,8539 .
\end{aligned}
$$

Value of the multiple determination coefficients $R^{2}$ of the simple and multiple linear regression equations (16) - (19) give a reason to assert that all of them have a good probability or credibility, however, except equation (16), their value is greater than 0,7 , and considerable part is rather close to one. Existence of the linear dependence between the resulting and factor variables also confirmed by obtained $F-$ criteria, that with probability $p=0,95$ is more greater than $\mathrm{F}_{\text {table }}=5,59$, that was calculated with assistance of $\mathrm{F}$ - Fisher distribution.

Analysis of the simple linear regression equations (16) - (17) displays, that small positive influence on gross regional product of Lvov region $\mathrm{y}_{6}$ have foreign direct investment in agriculture of Lvov region $\mathrm{y}_{8}(3.46)\left(\mathrm{B}_{8}=0,313\right)$ and investments in capital assets (agriculture of Lvov region) $\mathrm{y}_{10}(3.47)\left(\mathrm{B}_{10}=0,06034\right)$.

Study of the regression model (18) shows slight positive influence on gross regional product of Lvov region $\mathrm{y}_{6}$ of foreign direct investment in agriculture of Lvov region $\mathrm{y}_{8}\left(\mathrm{~B}_{8}=\right.$ 0,13442 ) and investments in capital assets (agriculture of Lvov region) $\mathrm{y}_{10}\left(\mathrm{~B}_{10}=0,04638\right)$, in particular, while increase foreign direct investment inflow in agriculture of Lvov region at 1 mln. USD and some constant or mean investments in capital assets (agriculture of Lvov region) value $y_{10}$ is expected to grow gross regional product of Lvov region $y_{6}$ by an average of 0,13442 bln. UAH; moreover increase of investment in fixed assets (agriculture) of Lvov region $\mathrm{y}_{10}$ at $1 \mathrm{mIn}$. UAH with an average or constant value of foreign direct investment in agriculture of Lvov region $\mathrm{y}_{8}$ will result in increment of gross regional product of Lvov region $\mathrm{y}_{6}$ in average at $0,04638 \mathrm{bln}$. UAH.

Analysis of the multiply linear regression equation (19) indicates moderate positive influence upon gross regional product of Lvov region $y_{6}$ of foreign direct investment in agriculture of Lvov region $y_{8}\left(B_{8}=0,12285\right)$ and investments in capital assets (agriculture of Lvov region) $y_{10}\left(B_{10}=0,02396\right)$ and negative influence - employee quantity increase in agricultural industry of Lvov region $\mathrm{y}_{9}\left(\mathrm{~B}_{9}=-138,50257\right)$.

Regression coefficients' values of the multiply regression model (20) argue some slight positive impact on gross regional product of Lvov region $\mathrm{y}_{6}$ of foreign direct investment in agriculture of Lvov region $\mathrm{y}_{8}\left(\mathrm{~B}_{8}=0,19455\right)$, financial results of general activity (agriculture) of Lvov region $\mathrm{y}_{7}\left(\mathrm{~B}_{7}=0,04147\right)$ and investments in capital assets (agriculture) of Lvov region $\mathrm{y}_{10}\left(\mathrm{~B}_{10}=0,02422\right)$, at the same time employees quantity grow in agriculture of Lvov region $\mathrm{y}_{9}$ will cause decrease of gross regional product of Lvov region $\left(B_{9}=-74,3949\right)$.

Finally, one should notice, because of small amount of input sample table (2) analysis of regression equations coefficients (19) i (20) have more qualitative than quantitative influence upon resulting variable $\mathrm{y}_{6}$.

\section{CONCLUSION}

In this research linear, parabolic, and exponential trend models of investments and main agricultural indicators of Lvov region of Ukraine were presented. All the models with probability $p=0,95$ are adequate experimental data for 2000-2009, that permit to make the prediction of investments and main agricultural indicators of the researched region by these models for 2010 and 2011. However, it should be pointed out, because of small amount of input data analysis of regression equations coefficients have more qualitative than quantitative influence upon resulting variable $\mathrm{y}_{6}$. 


\section{REFERENCES}

1. Carita A., Luyt I., Santos N. Emerging investment trends in primary agriculture. A review of equity funds and other foreign-led investments in the CEE and CIS region - FAO. 2013. - $141 \mathrm{p}$.

2. Crane K., Larrabee, F.S. Encouraging trade and foreign direct investments in Ukraine. RAND. $-2007 .-46$ p.

3. Vitale K. Environmental and Food Safety and Security for South-East Europe and Ukraine. - Springer Science+Business Media B.V. - 2012. - 272 p.

4. Yeleyko V.I., Kopych I.M., Bodnar R.D., Demchyshyn M.Y. Ekonometriya.: Navchal'nyj posibnyk. - Lviv: Vydavnytstvo LKA, 2007. - 349 s.

5. Yeleyko V.I., Yeleyko O.I., Synytskyy O.S., Chemerys A.O. Ekonometrychni metody prognozuvannya. - K.: Vydavnytstvo UADU, 1998. - $115 \mathrm{~s}$.

6. Yeleyko V.I., Ekonomiko-statystychni metody modelyuvannya I prognozuvannya. - K.: NMK VO, 1988. - $88 \mathrm{~s}$.

7. Yeleyko V.I., Osnovy ekonometriyi. - Lviv.: TzOV «MARKA Ltd», 1995. - Ch. 1. - $192 \mathrm{~s}$.

8. Gómez M.I., Gonzáles E.R., Melo L.F. Forecasting food inflation in developing countries with inflation targeting regimes // American Journal of Agricultural Economics . - 2011. Vol. 94(1). - P.153 - 173.

9. Ruff F. Methodological problems of classification and prediction in food marketing // Roczniki Naukowe Stowarzyszenia ekonomistów rolnictwa i agrobiznesu. 2008. - t. X. zeszyt 5. - S. 125-129.

10. Carnot N., Koen V., Tissot B. Economic forecasting and policy. - Palgrave Macmillan. 2011. $-495 \mathrm{p}$.

11. Mariano R.S., Tse Y.K Econometric forecasting and high-frequency data analysis. World Scientific. - 2008. - 180 p.

12. Gupta R., Kabundi A. Forecasting macroeconomic variables in a small open economy: a comparison between small- and large-scale models // Journal of Forecasting. - 2010. Vol. 29. - P.168 - 185.

13. http://www.Iv.ukrstat.gov.ua/

14. http://www.ukrstat.gov.ua/ 